Article

\title{
Cycling as a Sustainable Transport Alternative in Polish Cittaslow Towns
}

\author{
Agnieszka Jaszczak ${ }^{1, * \mathbb{D}}$, Agnieszka Morawiak ${ }^{2}$ and Joanna Żukowska ${ }^{2}$ (D) \\ 1 Department of Landscape Architecture, University of Warmia and Mazury, 10-719 Olsztyn, Poland \\ 2 Faculty of Civil and Environmental Engineering, Gdansk University of Technology, 80-233 Gdansk, Poland; \\ agnieszka.morawiak@pg.edu.pl (A.M.); joanna.zukowska@pg.edu.pl (J.Ż.) \\ * Correspondence: agnieszka.jaszczak@uwm.edu.pl
}

Received: 24 May 2020; Accepted: 18 June 2020; Published: 20 June 2020

check for updates

\begin{abstract}
It is well known that growing motor traffic in urban areas causes air pollution and noise which affects the environment and public health. It is hardly surprising then that cycling should be used as an alternative mode of transport, not just in major cities but also in smaller ones including those that are members of the Cittaslow network. Their approach is based on sustainable development, care for the environment and transport solutions which will support a healthy lifestyle, reduced energy consumption and fewer emissions. The objective of the article is to analyse how well cycling is used as a means of transport in Polish Cittaslow towns. For this purpose, an analysis was conducted to understand how towns use their transport space to ensure accessibility and road safety. Reference is made to revitalisation programmes of Cittaslow towns with focus on what has been done to improve and build cycle paths in each town and outside of it. The work uses the following research methods: analysis of the literature, analysis of documents, including analysis of road incidents and traffic count. It has been demonstrated that cycling infrastructure in the towns under analysis has been marginalised. As a result, recommendations and suggestions are given which may inform decisions on how to build and transform cycling infrastructure in Cittaslow towns and in similar towns in Poland and abroad.
\end{abstract}

Keywords: cycling; cycling routes; slow cities; traffic safety; sustainable mobility; urban planning

\section{Introduction}

Many high-growth regions worldwide have developed as a result of globalisation, urbanisation and sub-urbanisation processes, which also has an effect on transport and accessibility. People living in big conurbations have less and less time and make frequent and multiple trips during the day. The result is an increasing number of cars in cities. As a consequence, transport networks have to be built. This is a common problem, especially in city centres and dense developments [1-5]. Exhaust and $\mathrm{CO}_{2}$ emissions rise, making cities increasingly more polluted [6]. In addition, motor transport increases noise levels which has a direct effect on people's health and well-being [7]. Given the strong need to save natural resources and care for the environment and people's health, it is important to operate urban transport policies that are based on alternative environmental solutions. These are largely related to cycling infrastructure which needs to be accessible and safe. While big cities understand this and have already initiated or completed relevant projects, smaller towns lack a clear plan for integrating transport services with networks of cycling roads and ensuring the availability of bicycles.

The purpose of the work was to analyse the structure of how bicycles are used and how Cittaslow towns develop their cycling infrastructure in the context of safety, a better quality of the environment and living standards, and reducing dependence on what are now limited sources of energy. The article describes the area of the research, research methods and the results. The discussion looks at the 
degree of bicycle usage, the availability of cycle paths and cycling infrastructure, an analysis of cyclist accidents and an analysis of the Revitalisation Programme of Cittaslow Towns as regards the planning of cycling infrastructure. Based on the results, guidelines and recommendations have been formulated, followed by a summary. The following were the assumptions:

- The research looks at the environmental needs (fewer sources of pollution, noise, a better energy mix), safety (reduction in cyclist accidents), pro-health aspects (better health and fitness of the population) and spatial and infrastructural needs (improved access to cycling infrastructure) of small towns.

- The research was carried out in small towns because infrastructure and safety analyses and data were not available for these sites, unlike Poland's major cities and conurbations. Cittaslow towns were selected on purpose due to their unique character and programmes which give priority to the environment, reduction in emissions, improved energy mix, better safety and health standards of the population.

- The research units were selected specifically for not having or having hardly any cycling infrastructure or cycle paths (per $\mathrm{km}$ ).

- There is a close relation between a lack of infrastructure or poor access to infrastructure and cycling as well as road safety in towns and especially outside them (e.g., for commuters).

- The research takes account of the importance of daily cycling by residents of small towns and making sure that the infrastructure meets those needs rather than just those of tourism, a seasonal phenomenon (being part of cycling trails). For this reason, the research does not include major tourist trails and their tourist infrastructure; instead, the work focuses on sections in and around small towns.

\section{Literature Review}

\subsection{Policy of Green Cycling Infrastructure in the Context of Increasing Urban Cycling}

With a stronger focus on the strategy of green transport, the need to design transport space is of key importance [8-11]. We know from research that the biggest cities in Germany, Austria and Switzerland have significantly reduced the share of car trips in the last twenty-five years, despite high rates of motorization. The key to their success was a coordinated transport and spatial policy which has made car trips slower, less comfortable and more costly and, as a result, has discouraged people from taking them $[12,13]$. The policy has also contributed to better safety, comfort and accessibility of pedestrian and cyclist solutions, with German towns putting in a lot more work into promoting cycling [12]. While Poland has also seen a rise in cycling just as in other European countries, the scale of cycling and access to cycling infrastructure is disproportionately smaller than that in German-speaking countries, the Netherlands or Scandinavian countries. Despite that, the bicycle is becoming an alternative to the car or public transport [14], not just in major cities but more and more also in medium-sized and small towns. There are, however, no guidelines on how to plan for cycling space in small towns or how to link cycle paths into a network to ensure easy and safe cycling in the town and outside it. Cycling in towns has a lot to offer. One of the advantages includes time saved, especially where motorised traffic is very heavy [15]. Cycling helps to avoid congestion and allows riders to pick a route which is convenient for them. In addition, cycling as a means of transport helps to improve the environment [16-18]. Studies show that factors which are not related to transport are important. They include the geographic conditions or landscape along commuter routes and the role of the city-specific cycling culture [19]. As a consequence, the location of cycling routes matters a lot. Cycling routes should be ideally designed to run across green spaces in a city, such as parks, squares, leisure spots by the water and city forests [20]. Bicycles are cost-efficient [21], do not emit dangerous substances, reduce the use of dwindling resources of energy and can help to fight lifestyle diseases. Increasing interest in cycling as a means of transport could help reduce traffic congestion and carbon emissions, to which the use of motor vehicles makes a large and inequitably distributed 
contribution [22]. Another reason why it makes sense to have an urban "pro-cycling policy" and the related economic, social and environmental benefits is the city bike system [23,24]. As shown in research by Scotini and colleagues [25], a comprehensive urban cycling policy and the introduction of a cycling transport system can also help to create more jobs.

\subsection{The Importance of Cycling for Health}

Cycling as a means of transport is good for people's health and changes city dwellers' health and well-being [6,26-29]. It is clear from research that cycling has a positive effect on cardio-respiratory performance, especially in youth. Even a daily commute helps to reduce the risk of cancer, respiratory and heart diseases, overweight and obesity [22,30,31]. Cycling on a daily basis, e.g., commuting for half an hour and more, may replace physical activity without spending the extra time on physical exercise [32-34]. What is more, if used as a daily physical activity, such mobility is cheap, simple and works for people in different states of physical fitness and age. More cycling would bring additional public health benefits thanks to a reduced use of the car which, by the same token, would reduce air pollution, noise and general road traffic risks [34,35].

\subsection{Road Safety in the Context of the Risk of Cyclist Accidents}

How likely people are to cycle depends largely on how unsafe cycling is due to a lack of cycling infrastructure (cycle paths). Research conducted by Gutierrez and colleagues [36] in South America shows that the risk of an accident or assault may outweigh the economic savings and health benefits of cycling [37]. The United States represents a similar case where cycling is a safety problem because the infrastructure and access to cycle paths is not ensured [34,38]. Using examples from Japan, the US and Canada, Reynolds and colleagues [39] show that the type of road infrastructure has an effect on cyclist safety and risk of injury. They emphasise that cyclists feel the least safe at multi-lane junctions such as roundabouts, on pavements or combined routes. Cyclists do feel safe, however, on dedicated cycling routes or cycle paths, marked as such. A study in Dublin showed that cyclists perceive cycling around Dublin as less safe compared to using other modes of transport and their sense of safety drops when they realise they could be involved in a bus accident [40].

Sometimes safety and using cycle paths may be related to people's cultural and social backgrounds, as demonstrated in a study of four culturally different urban regions in the United Kingdom [41] and in the United States [38]. There may also be geographic and climatic conditions [42,43]. Polish studies conducted in 2015 by the Ministry of Sport and Tourism show that nearly half of people who regularly cycle to work do not feel safe cycling on a street (definitely or rather not safe) and more than one third of respondents believe the cycling infrastructure is not good enough to ensure a safe trip [44]. Comparative studies carried out by Pucher [34] in Germany and the Netherlands show that if applied, a long-term cycling strategy and cycling infrastructure policy, combined with educating people on alternative forms of transport, can in fact achieve good results such as fewer cyclist accidents and decreased accident fatality rates. This shows that better safety should be a key objective for promoting cycling to minimize the negative consequences of cyclist accidents and eliminate the barriers of a lack of safe infrastructure [33-45].

\subsection{The Importance of Building Cycling Infrastructure in Cittaslow Towns}

While urban cycling looks optimistic within major cities, it has very little bearing on small towns. Although small towns and rural areas are now better able to manage their transport and cycling space, the cycling infrastructure is still underdeveloped. This may be because cycling is not a popular mode of transport and funding is limited. Cittaslow network towns offer some ideas on ways to organise free movement, "slow" living and "liveability". Cittaslow as a movement goes back to 1998. The association has its seat in Orvieto, in Italy's Umbria region. Italian towns became a model for other European and then worldwide towns. Eventually, an international movement was formed to improve the quality of life of inhabitants, celebrate a "free" and healthy lifestyle and conserve the natural and cultural 
environment of small towns [46,47]. Towns applying for membership declare that they will work to meet the qualification requirements such as creating people-friendly places. Cittaslow network towns agree to plan public space, develop transport infrastructure which will offer convenience and quality of life to residents and ensure that it is accessible for disabled and older people. Slow means a sustainable urban development which plans for living and transport space that will improve living conditions and ensure better access to public functions for residents [48-50]. While these ideas are sadly not implemented often, Cittaslow towns understand the need for changing the way they think about transport and swapping the car for the bicycle. Proposals to improve transport space or build new transport infrastructure should take account of accessibility, better access and road safety which includes cycle safety.

\subsection{Traffic Counts in Poland in Relation to the Legal Background}

In accordance with Article 20.15 of the Public Roads Acts of 21 March 1985 (Journal of Laws 2020, item 470), road authorities are required to measure road traffic periodically [51]. Traffic counts are Poland's primary source of road traffic information. The data support how road infrastructure is managed, planned and developed, including decisions to build and upgrade infrastructure, withdraw projects and eliminate some elements of roads. Regular traffic studies in Poland began in the interwar period in the 20th century, concentrating on cities and major routes when they were particularly busy. Rural studies began in 1926 and were conducted three times every four years. In 1965, the traffic count system was harmonised into measurements run regularly every five years, as set out in the guidelines of the United Nations Economic Commission for Europe. In 1985, for economic reasons the study was carried out on national roads only. Since 2000, following Poland's new administrative division, traffic counts have been conducted every five years separately for national and regional roads [52]. Traffic counts cover the following vehicles: motorcycles, passenger cars and minibuses, light trucks, trucks with and without trailers, buses, tractors and bicycles. Bicycles using regional roads in the region of Warmia and Mazury have only been included since 2010.

\section{Materials and Methods}

\subsection{The Study Area}

Associated in the Cittaslow network, the towns under analysis are found in Warmia and Mazury, a region commonly known as the Green Lungs of Poland. The region is mostly agricultural and has a strong focus on environmental protection. With very little industry and services, the region is popular with people from Poland's big cities as a place to relax or have second homes (mostly summer homes). Twenty-two towns from Warmia and Mazury have joined the association, representing different environmental, spatial, economic and demographic conditions (as of 2020). The international network includes towns whose population does not exceed 50,000. In Warmia and Mazury, most of the towns are small with a population of up to 10,000 and slightly more; only two have a population of more than 20,000. The area they occupy ranges from $2.16 \mathrm{~km}$ (Bisztynek) to $16.84 \mathrm{~km}$ (Lubawa), see Figure 1.



Figure 1. The Warmia and Mazury region and towns associated in Cittaslow Poland. Source: Own elaboration based on www.invest.warmia.mazury.pl, www.Cittaslowpolska.pl and Google Maps. 
Considering the availability of traffic data, Cittaslow towns were divided into two groups. The first group includes towns in which cycle traffic was measured on selected sections of streets in built-up areas. They are Braniewo, Biskupiec, Bartoszyce, Dobre Miasto, Działdowo, Gołdap, Lidzbark Warmiński, Lidzbark, Lubawa, Nidzica, Nowe Miasto Lubawskie, Orneta and Reszel. Group two includes towns in which traffic was measured on selected sections of roads outside of the Cittaslow towns which pass through them. They are Bisztynek, Barczewo, Górowo Iławeckie, Jeziorany, Olsztynek, Pasym, Ryn and Wydminy. Because ADT (average daily traffic) in Sępopol is not available, the town is not covered by this analysis (Table 1 ).

Table 1. Division of the towns by sections of urban and rural roads.

\begin{tabular}{cccc}
\hline \multicolumn{2}{c}{ Sections in Built-Up Areas } & \multicolumn{2}{c}{ Sections Beyond the } \\
\hline Town & Street & Town & Road Section \\
\hline Braniewo & Elbląska & Bisztynek & Bartoszyce-Bisztynek \\
Biskupiec & Kościuszki & Barczewo & Olsztyn-Barczewo \\
Bartoszyce & Kętrzyńska & Górowo Iławeckie & Górowo \\
& Iławeckie-Bartoszyce \\
Dobre Miasto & Łużycka & Jeziorany & Miasto-Jeziorany \\
Działdowo & Olsztyńska & Olsztynek & Olsztynek-Zgniłocha \\
Gołdap & Paderewskiego & Pasym & Olsztyn-Pasym \\
Lidzbark Warmiński & Olsztyńska & Ryn & Sterławki Wielkie-Ryn \\
Lidzbark & Piaski & Wydminy & Kap-Wydminy \\
Lubawa & 19 Stycznia & & \\
Nidzica & 1-go Maja & & \\
Nowe Miasto & Wojska Polskiego & & \\
Lubawskie & 1-go Maja & & \\
Orneta & Słowiańska & & \\
Reszel & Source Own & \\
\hline
\end{tabular}

Source: Own elaboration of authors.

To analyse the Supra-Local Revitalisation Programmes of Cittaslow Towns for their cycling infrastructure projects, fourteen and then nineteen towns were selected which had their programme developed in 2015, 2016-2017 and 2019. The towns are: Barczewo, Biskupiec, Bisztynek, Dobre Miasto, Działdowo, Gołdap, Górowo Iławeckie, Lubawa, Nidzica, Nowe Miasto Lubawskie, Olsztynek, Pasym, Reszel, Ryn; and from 2019: Bartoszyce, Działdowo, Lidzbark and Orneta.

\subsection{Methods of Cycle Counts in 2010 and 2015}

Average daily traffic was measured and counted by ZDW Olsztyn (Provincial Road Administration) [53] and GDDKiA (General Directorate for National Roads and Motorways) in 2010 and 2015 according to the "Guidelines of general traffic counts on regional roads" $[54,55]$ and the "Guidelines for the organisation and completion of general traffic counts on national roads" [56,57] for 2010 and 2015 respectively, published by the Department of Roads and Motorways of the Ministry of Infrastructure and Development and the GDDKiA. Traffic counts on road sections in the towns were conducted manually, semi-automatically and automatically (on national roads). Cycle traffic was measured for entire road cross-sections (road, pavements and cycle paths) (Figure 2). 


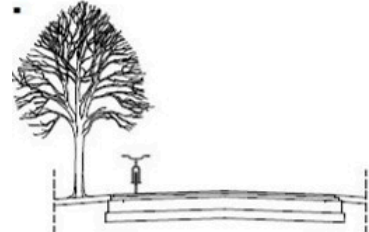

a

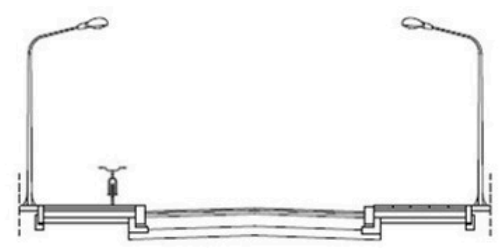

b

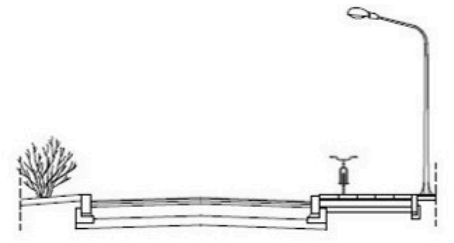

Figure 2. Cross-section of a road with shoulders (a), street cross-section with a pavement and cycle path (b), street cross-section with a cycle path and shoulder (c). Source: Own elaboration of authors.

Three categories of measurement points were used. The first category is type $\mathrm{P}$ and defines measurement points where counts are conducted during all hours. Data from these sections help to determine coefficients rates for enlarging samples for those sections which are not studied during all hours (W type). Type $\mathrm{M}$ includes sections which run across the towns which also have counts conducted during all hours. Type $\mathrm{W}$ are other sections where counts are conducted during limited hours. The annual count includes five so-called daily periods $\left(X_{1}-X_{4}, X_{6}\right)$ and one night period $\left(X_{5}\right)$ which is only included in type $P$ and $M$ points. In the case of type $P$ and $M$, a count during all hours means 16 hours from 6:00 am to 10:00 pm and limited hours for $\mathrm{W}$ category means eight hours from 8:00 am to 4:00 pm. Night counts were conducted from 10:00 p.m. to 6:00 a.m. The ADT for particular road sections was calculated for specific measurement points. The formula below was applied both to motor vehicles and bicycles (in the case of bicycles the total number of motor vehicles was replaced with the total number of bicycles) and was applied to type $\mathrm{P}$ and $\mathrm{M}$ points [54-57].

$$
A D T=R_{N}+\frac{M_{R} \times N_{1}+0.85 M_{R} \times N_{2}+M_{N} \times N_{3}}{N} \text { (veh./day) }
$$

where:

$A D T$ - total average daily traffic of motor vehicles;

$M_{R}$-average daily traffic on workdays (from Monday to Friday, 6:00 a.m.-10:00 p.m.);

$0.85 M_{R}$ - average daily traffic on Saturdays and days before public holidays (6:00 a.m.-10:00 p.m.);

$M_{N}$-average daily traffic on Sundays and public holidays (6:00 a.m.-10:00 p.m.);

$R_{N}$-average night traffic (10:00 p.m.-6:00 a.m.);

$N_{1}$-number of workdays in 2010 and 2015;

$N_{2}$-number of Saturdays and days before public holidays in 2010 and 2015;

$\mathrm{N}_{3}$-number of Sundays and days before public holidays in the year;

$N$-number of all days in the year.

The values of $M_{R}, M_{N}$ and $R_{N}$ were calculated as follows:

$$
\begin{aligned}
& M_{R}=\frac{1}{3} \times\left(X_{1}+X_{2}+X_{4}\right)(1,2,4 \text { measurements on workdays }) \\
& M_{N}=\frac{1}{2} \times\left(X_{3}+X_{6}\right)(3,6 \text { measurements on Sundays and public holidays }) \\
& R_{N}=X_{5}
\end{aligned}
$$

To calculate ADT for type $\mathrm{W}$ points, eight-hour traffic was converted into sixteen-hour traffic using the sample extension coefficient from type $\mathrm{P}$ points assigned to type $\mathrm{W}$ points (for each type $\mathrm{W}$ point a type $\mathrm{P}$ point should be assigned located on the road that has the same number).

$$
r_{i j}=\frac{X_{i j}}{Y_{i j}}
$$

where: 
measurement $i$ at point $j$;

$X_{i j}$-number of total motor vehicles between 6:00 am-10:00 pm (measurement $i$ at point $j$ );

$Y_{i j}$-number of total motor vehicles between 8:00 am-04:00 pm (measurement $i$ at point $j$ ).

In the next stage of calculating ADT for point $\mathrm{W}$, night traffic was calculated based on the assigned type P points. The final ADT for type W points was calculated using the formula in Equation (1) just like for points type $P$ and $M$.

The 2010 and 2015 General Traffic Counts, which include ADT for cycling, helped to identify differences between Cittaslow towns' cycle traffic over a period of five years by road sections and outside Cittaslow towns. In addition, a point was made about the relation between cycle traffic and availability of cycle paths and cyclist safety based on cyclist accidents. The results show how the Cittaslow towns were able to deliver on cycling infrastructure in a period of five years and what needs to be done to develop the cycling infrastructure and promote the bicycle as a means of transport in the towns under analysis.

\subsection{Analysis of Cyclist Accidents}

Cyclist accidents were analysed using accident data from the National Police in Warsaw System of Accident and Collision Data. The statistics is delivered in annual national "Road Accident Reports", while detailed data including cyclist data is passed on to road authorities via the Regional Police. The analysis used cyclist accident and collision data from the database of the Regional Roads Authority in Olsztyn [52].

\subsection{Analysis of the Supra-Local Revitalisation Programme of Cittaslow Towns for Their Cycling Infrastructure}

The operating goals of the revitalisation programme are designed to improve the quality of the environment. They address issues such as better quality of the environment, increased environmental awareness and pro-environmental attitude of the communities and promoting environmentally friendly means of transport [53]. In addition, the Supra-Local Revitalisation Programme of Cittaslow towns is consistent with the following investment priorities set out in priority axes of the Warmia and Mazury Regional Operational Programme for the Years 2014-2020: 7b "Increase regional mobility by linking secondary and tertiary hubs with TEN-T infrastructure, including multimodal hubs"-Axis 7 Transport Infrastructure [58]. The study analysed all projects which were submitted to the revitalisation programme in 2015 and selected only those projects which tackled the revitalisation or construction of new infrastructure in the town. Because the towns developed their individual revitalisation programmes in the subsequent years (2016-2017) that are partly based on the 2015 programme, an analysis was carried out of the planning of cycling infrastructure projects and how they have been delivered. The first programme [59] and the individual programmes (2016-2017) were developed for fourteen Cittaslow towns. The last stage was to analyse the supplemented Supra-Local Revitalisation Programme of Cittaslow Towns 2019 (second programme), [60]. Four more towns joined the programme and were included in the study conducted at that time. Below are project topics, measures and locations as regards the planning of cycling infrastructure for fourteen towns (according to the first programme), Table 2. 
Table 2. Planned projects involving cycling infrastructure in Cittaslow towns (as of 2015).

Title of Comprehensive Project (PK), Sub-Measure (P) and Location (L)
PK: Develop the Old Town's public space
P1: Prepare cycling and walking routes
Barczewo
P2: Plan leisure infrastructure in the centre of the Old Town, prepare a cycling and
walking route
L: Old Town

PK: Improve the site by creating a leisure and sensory park

P1: Build a path for pedestrians and cyclists

L: Park at Staw Garncarski pond

Górowo Iławeckie

PK: Improve the area in the valley of the river Młynówka-project on reserve list

P: Build a walking and cycling path and link the site to Eastern Poland Cycling Routes and other sites in the town

L: City Lagoon, valley of the river Młynówka

\begin{tabular}{|c|c|}
\hline $\begin{array}{c}\text { Lidzbark } \\
\text { Warmiński }\end{array}$ & PK: No main project in the revitalisation programme to address cycling infrastructure \\
\hline Lubawa: & $\begin{array}{l}\text { PK: Revitalisation of selected sites to meet the need for exercise therapy for socially } \\
\text { excluded people } \\
\text { P: Build a walking and cycling path Zalew-Lipy } \\
\text { L: Kopernika street across parts of Lipowa street and Pielgrzyma street to Kupnera } \\
\text { street }\end{array}$ \\
\hline Nidzica & PK: No main project in the revitalisation programme to address cycling infrastructure \\
\hline $\begin{array}{l}\text { Nowe Miasto } \\
\text { Lubawskie }\end{array}$ & $\begin{array}{c}\text { PK: Integration and engagement of socially excluded people in the revitalised area } \\
\text { through recreation and physical activity } \\
\text { P: Build a cycle road on the railway embankment in place of the disused } \\
\text { Brodnica-Iława train line and implement the city bike project } \\
\text { L: City Park, site in the post-railway area }\end{array}$ \\
\hline Olsztynek & $\begin{array}{c}\text { PK: Build a health path "Healthy body, healthy spirit" } \\
\text { P: Build a health path and implement the city bike project } \\
\text { L: Urban and sub-urban areas }\end{array}$ \\
\hline Pasym & PK: No main project in the revitalisation programme to address cycling infrastructure \\
\hline Reszel & $\begin{array}{l}\text { PK: Restore the natural, architectural and functional features of City Park. } \\
\text { P: Build a health path } \\
\text { L: City Park }\end{array}$ \\
\hline Ryn & PK: No main project in the revitalisation programme to address cycling infrastructure \\
\hline
\end{tabular}

Source: Prepared by the author based on Cittaslow Supra-Local Revitalisation Programme of Cittaslow Towns of 2015. 
When analysing the Supra-Local Revitalisation Programme of Cittaslow Towns of 2015 [59] and subsequent documents from 2016-2017 and 2019 [60], the following issues were considered:

- the degree to which planned cycling infrastructure projects were changed in subsequent years;

- the scale of planned cycling infrastructure projects, including their location and length of cycle paths;

- priority given to cycling infrastructure projects over other projects;

- the degree of connectivity with existing infrastructure and its size in the town and outside it;

- availability of cycling infrastructure, especially in suburban areas;

- the goals of cycling infrastructure projects including social, environmental, health and transport goals.

\section{Results and Discussion}

All of the Cittaslow towns in Warmia and Mazury analysed in this article have a strong and sadly unused potential for planning and building cycling infrastructure. This is particularly important in the case of the small towns of Warmia and Mazury because cycling there should reflect the local needs while drawing on models from countries which use the bicycle as a basic means of daily transport, whether in towns or outside of them. The bicycle is becoming an inseparable tool for sports or spending free time but it should also become one of the forms of commuting. Many people living in suburbs or in the countryside work in a Cittaslow town. As we know from Biostat's "Transport behaviour of Polish people" study, 20.9\% of respondents are not happy with the number of public transport services between where they live and neighboring towns. In addition, approximately $8.4 \%$ of respondents said they did not have a car [61]. As a consequence, for some people cycling may become the only alternative for moving between towns. Therefore, an important stage in the study was to analyse cycle traffic on urban and rural sections.

\subsection{Results of Studies into the Number of Bicycles Used}

Cycling is a great alternative in urban spaces and for travelling between towns. It is very difficult, however, to identify the number of bicycles in Poland. Bicycles do not have to be registered under Polish law. To get a better understanding of the data and numbers, a 2011 report of the Central Statistical Office (GUS) will be presented which is based on the National Census (NSP) run every ten years, and on regular surveys. The survey looks at a household's possession of durable items (the bicycle) and overall number of households (an NSP survey). According to the National Census, there were about 13,567,999 households in 2011 in Poland, with about 515,857 in the region of Warmia and Mazury [62]. In addition, regular surveys showed that in 2011 an average of $62.9 \%$ households in Poland had a bicycle with $60.5 \%$ in the region of Warmia and Mazury [63]. It is safe to say that in all of Poland in 2011 there were about 8,534,270 bicycles, with about 312,090 bicycles in Warmia and Mazury in 2011. As we can see from an analysis of cycling used as a means of transport in the Cittaslow towns, cycle traffic increased over the five years between 2010 and 2015. In one case only-in the town of Biskupiec, traffic in 2015 fell compared to 2010 by about 31 bicycles per day. The highest increase in cycle traffic was recorded in the town of Działdowo where in 2015 there were 279 bicycles per day, which is more than double the 2010 figures which were 104 bicycles per day (Figure 3).

Figure 4 shows results that differ from the ones above. The distribution of increasing and decreasing traffic between 2010 and 2015 is equal. On the road sections Sterławki Wielkie-Ryn, Dobre Miasto-Jeziorany, Górowo Iławeckie-Bartoszyce and Olsztyn-Barczewo bicycles per day increased, while on the road sections Kap-Wydminy, Olsztyn-Pasym, Olsztynek-Zgniłocha and Bartoszyce-Bisztynek a decrease was recorded. The biggest difference in cycle traffic was recorded on the section Kat-Wydminy where in 2010 there were 71 bicycles per day and only 39 in 2015. The biggest increase in volumes was recorded on the section Dobre Miasto-Jeziorany, however, it was only an extra 16 bicycles. 


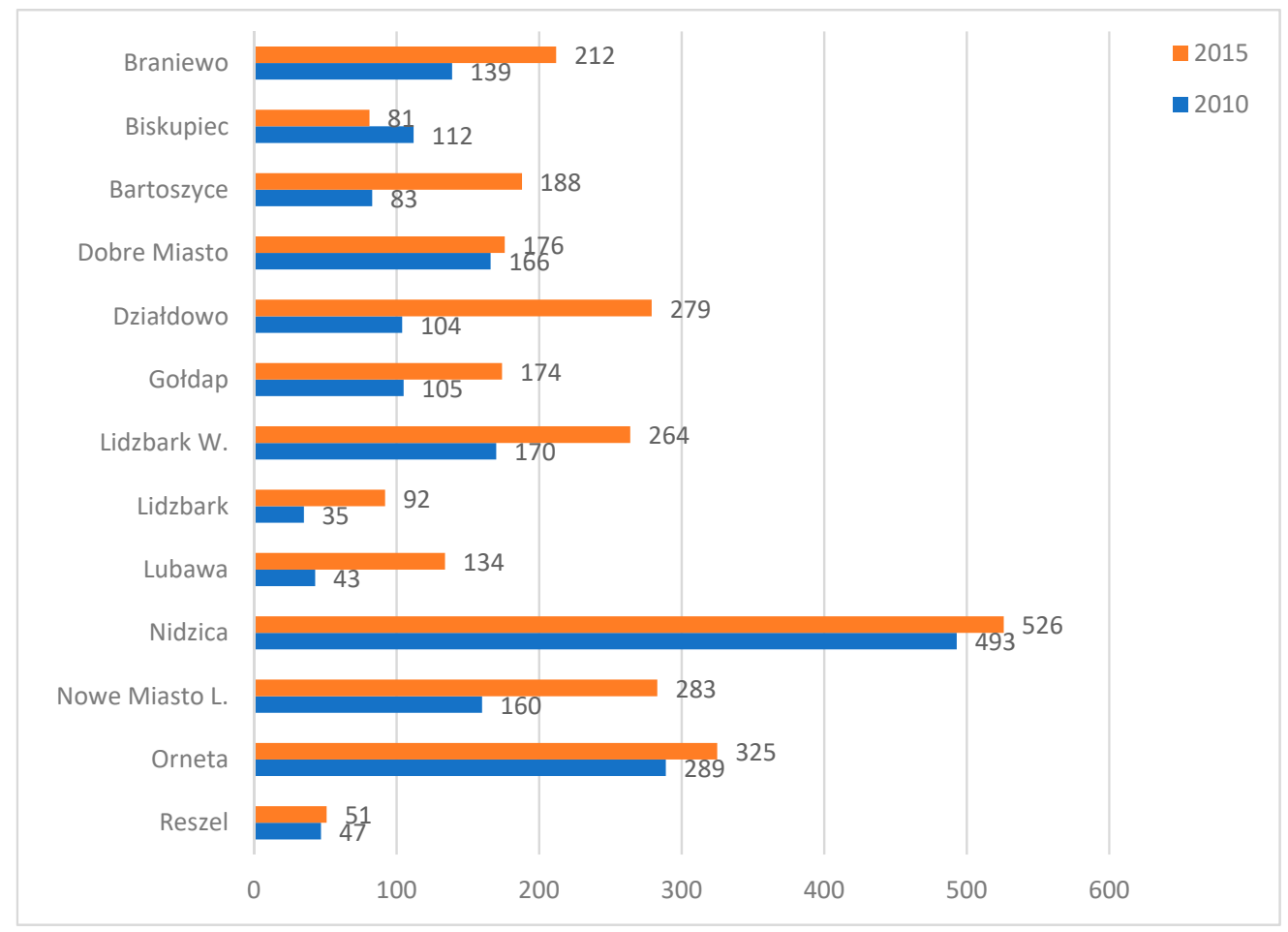

Figure 3. Comparison of ADT 2010 and 2015, built-up area in a Cittaslow town. Source: Own elaboration of authors based on ZDW Olsztyn [53].

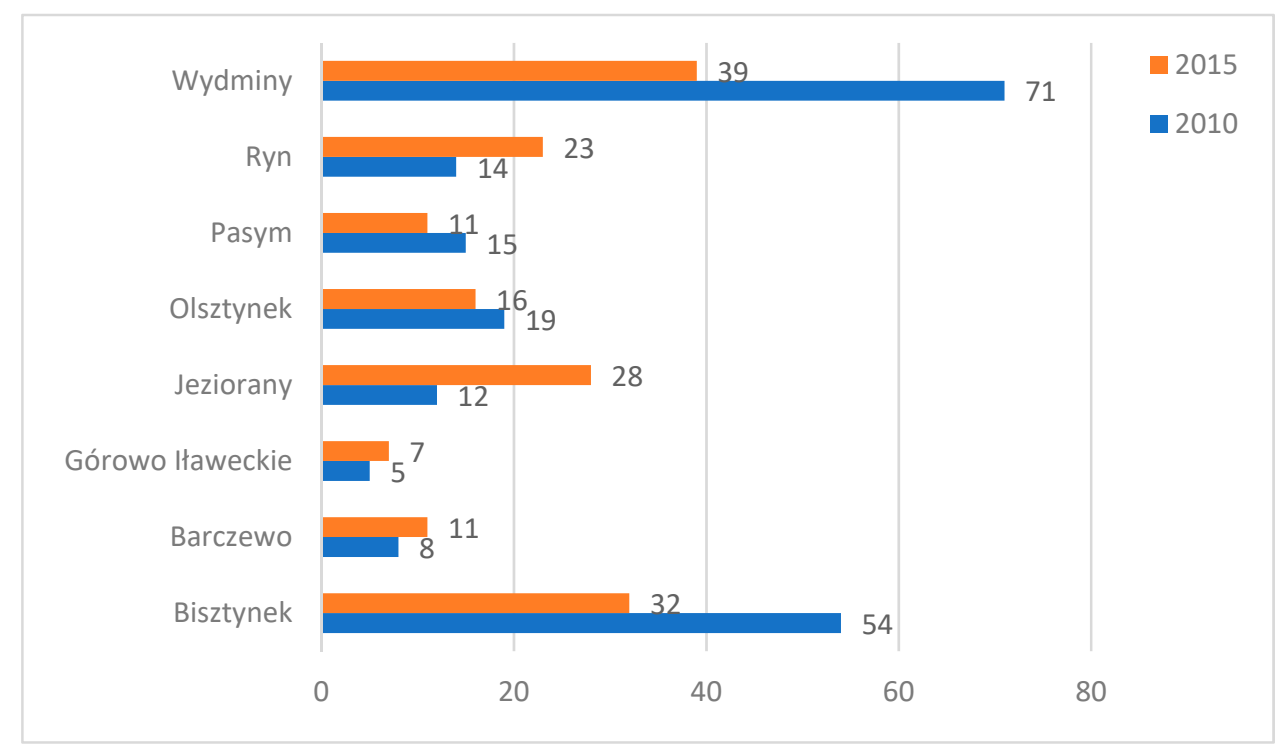

Figure 4. Comparison of ADT 2010 and 2015, road section outside Cittaslow towns. Source: Own elaboration of authors based on ZDW Olsztyn [53].

To recap, it should be said that while cycling increases, it does so only on road sections in built-up areas of Cittaslow towns. This may be mainly because the bicycle is gaining popularity as a means of urban transport and is related to availability of cycling infrastructure. Outside of built-up areas cycling has decreased which suggests that cyclists do not feel safe when they use the same road with the ever-increasing volume of motor vehicles and trucks (Figures 5 and 6). 




Figure 5. Comparison between traffic volumes for all vehicles and cycle traffic on regional roads. Source: Own elaboration of authors based on ZDW Olsztyn [53].
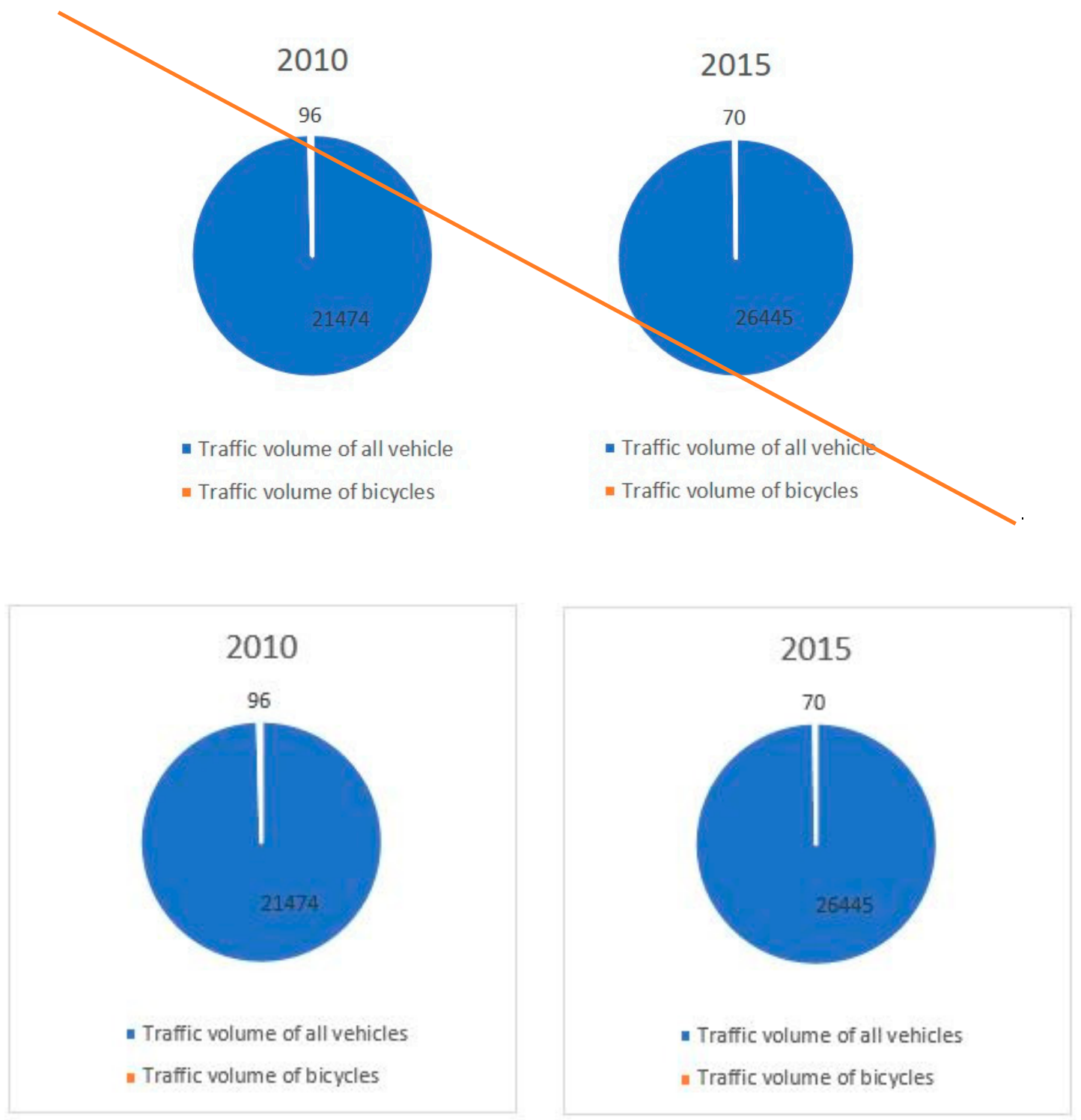

Figure 6. Comparison between traffic volumes for all vehicles and cycle traffic on national roads. Source: Prepared by the author based on GDDKiA Olsztyn data [64]. 
The charts show that cycling continues to be a fraction of overall traffic. In 2010, the share of bicycles in overall traffic of all vehicles using regional roads in Cittaslow towns accounted for a mere $2.39 \%$, and $3.03 \%$ in 2015. This is even more striking in the case of national roads in Cittaslow towns, where in 2010 the relation between bicycles and all vehicles was $0.44 \%$ and in 2015 only $0.26 \%$.

\subsection{Results of Studies into Cycle Path and Cycling Infrastructure Coverage}

According to the Local Data Bank in Poland, in 2011 there were $5782.8 \mathrm{~km}$ of cycle roads and in 2015 there were 10,797.2 km, an increase of about 100\% (5014.4 km) [60] (Figure 7). The data show cycle roads which are managed by municipalities, counties and regional governments. This means they are roads within a road, roads that are separate from the main road and the pavement and are a walking and cycling zone. The data looks at the length of one-way roads. In the case of roads which are on both sides of the roadway, the length is calculated separately. The list does not include roads which are tourist routes [62]. The local data bank has data for the years 2011-2019 but there is no data for 2010. The years 2011-2015 show that the number of cycle paths rose in Poland each year which suggests that in 2010 cycle road length was less than $5000 \mathrm{~km}$.

Analysis of road infrastructure data shows that cycle traffic has grown the most on pedestrian and cycle paths or cycle paths built from 2010 to 2015 (Bartoszyce, Działdowo, Lidzbark Warmiński, Lubawa, Nidzica, Orneta) (see Table 3). In addition, cycling also intensified in three towns which do not have cycling infrastructure. They are Braniewo, Gołdap and Nowe Miasto Lubawskie. They are, however, important tourist destinations with Green Velo, Poland's longest signed cycle route, passing through Braniewo and Gołdap.

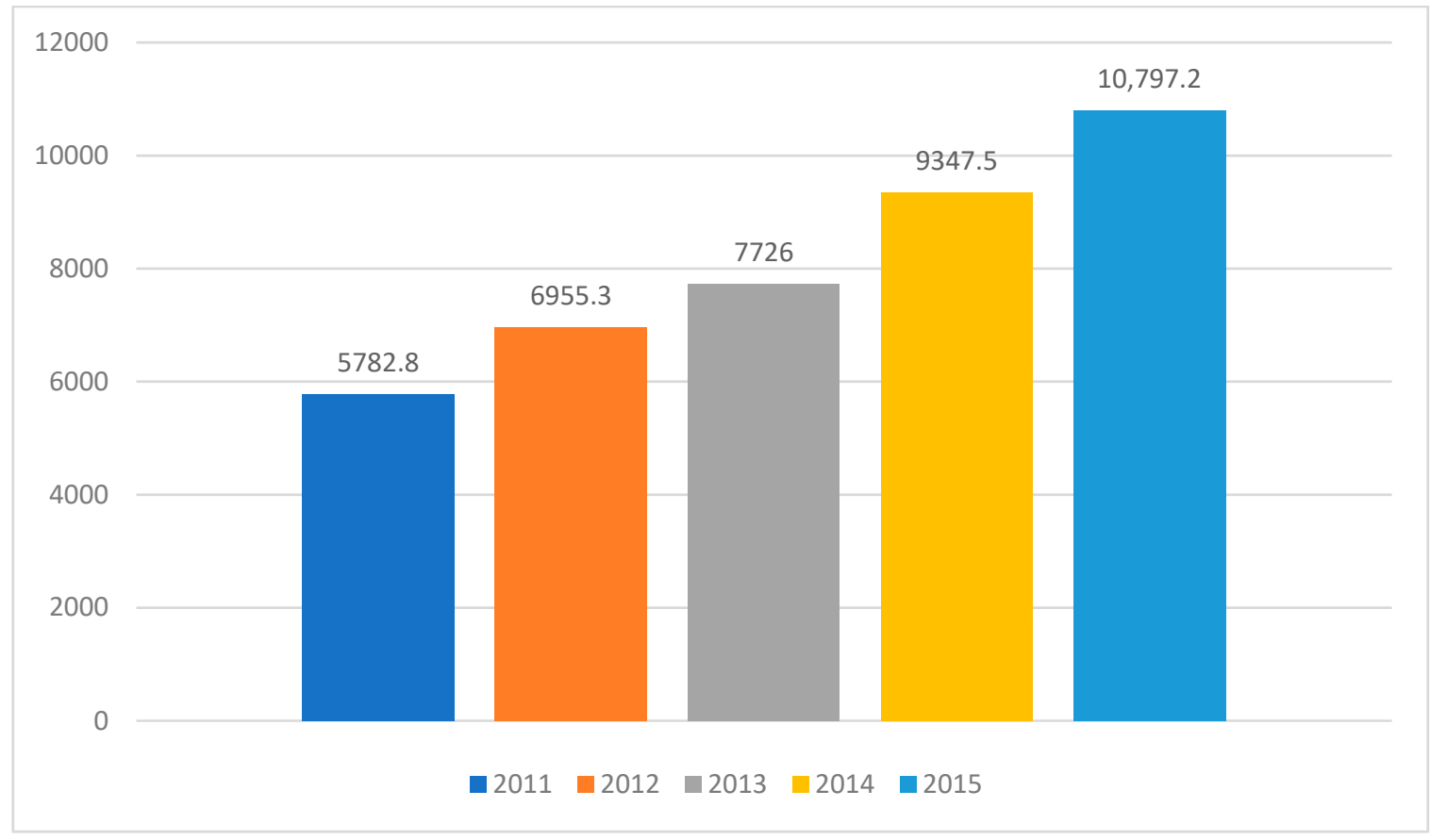

Figure 7. Comparison of the length of cycle roads in Poland 2011-2015. Source: Own elaboration of authors based on Bank Danych Lokalnych bdl.stat.gov.pl [62]. 
Table 3. Cycle traffic and existing cycling infrastructure. Source: Own elaboration of authors based on ZDW Olsztyn, GDDKiA Olsztyn.

\begin{tabular}{|c|c|c|c|c|c|c|}
\hline No & Town & $\begin{array}{c}\text { Road } \\
\text { Category* }\end{array}$ & $\begin{array}{l}\text { Study } \\
\text { Area ** }\end{array}$ & $\begin{array}{l}\text { ADT } \\
2010\end{array}$ & $\begin{array}{l}\text { ADT } \\
2015\end{array}$ & Cycling Infrastructure \\
\hline 1 & Braniewo & $\mathrm{P}$ & $\mathrm{T}$ & 139 & 212 & $\begin{array}{l}\text { No dedicated infrastructure, cyclists } \\
\text { use the pavement or road }\end{array}$ \\
\hline 2 & Biskupiec & $\mathrm{P}$ & $\mathrm{T}$ & 112 & 81 & $\begin{array}{c}\text { No dedicated infrastructure, cyclists } \\
\text { use the pavement or road }\end{array}$ \\
\hline 3 & Bartoszyce & $\mathrm{P}$ & $\mathrm{T}$ & 83 & 188 & $\begin{array}{l}\text { In } 2012 \text { a walking and cycling zone } \\
\text { was built, about } 2 \mathrm{~km} \text { long }\end{array}$ \\
\hline 4 & Dobre Miasto & $\mathrm{P}$ & $\mathrm{T}$ & 166 & 176 & $\begin{array}{c}\text { No dedicated infrastructure, cyclists } \\
\text { use the pavement or road }\end{array}$ \\
\hline 5 & Działdowo & $\mathrm{P}$ & $\mathrm{T}$ & 104 & 279 & $\begin{array}{c}\text { In } 2014 \text { about } 2.5 \mathrm{~km} \text { of cycle paths } \\
\text { were built }\end{array}$ \\
\hline 6 & Gołdap & $\mathrm{P}$ & $\mathrm{T}$ & 105 & 174 & $\begin{array}{c}\text { No dedicated infrastructure, cyclists } \\
\text { use the pavement or road }\end{array}$ \\
\hline 7 & $\begin{array}{c}\text { Lidzbark } \\
\text { Warmiński }\end{array}$ & $\mathrm{P}$ & $\mathrm{T}$ & 170 & 264 & $\begin{array}{c}\text { In } 2014 \text { about } 0.6 \mathrm{~km} \text { of a walking and } \\
\text { cycling zone were built }\end{array}$ \\
\hline 8 & Lidzbark & $\mathrm{P}$ & $\mathrm{T}$ & 35 & 92 & About $1.2 \mathrm{~km}$ of cycle paths were built \\
\hline 9 & Lubawa & $\mathrm{P}$ & $\mathrm{T}$ & 43 & 134 & $\begin{array}{c}\text { In } 2014 \text { about } 1.0 \mathrm{~km} \text { of a walking and } \\
\text { cycling zone was built }\end{array}$ \\
\hline 10 & Nidzica & $\mathrm{P}$ & $\mathrm{T}$ & 493 & 526 & $\begin{array}{l}\text { In } 2014 \text { about } 6 \mathrm{~km} \text { of a walking and } \\
\text { cycling zone were built }\end{array}$ \\
\hline 11 & $\begin{array}{l}\text { Nowe Miasto } \\
\text { Lubawskie }\end{array}$ & $\mathrm{P}$ & $\mathrm{T}$ & 160 & 283 & $\begin{array}{c}\text { No dedicated infrastructure, cyclists } \\
\text { use the pavement or road }\end{array}$ \\
\hline 12. & Orneta & $\mathrm{P}$ & $\mathrm{T}$ & 289 & 325 & $\begin{array}{c}\text { In } 2014 \text { about } 2.0 \mathrm{~km} \text { of a walking and } \\
\text { cycling zone and } 0.15 \text { of a cycle path } \\
\text { were built }\end{array}$ \\
\hline 13 & Reszel & $\mathrm{P}$ & $\mathrm{T}$ & 47 & 51 & $\begin{array}{c}\text { No dedicated infrastructure, cyclists } \\
\text { use the road }\end{array}$ \\
\hline 14 & Bisztynek & $\mathrm{N}$ & OT & 54 & 32 & $\begin{array}{c}\text { No dedicated infrastructure, cyclists } \\
\text { use the pavement or road }\end{array}$ \\
\hline 15 & Barczewo & $\mathrm{N}$ & OT & 8 & 11 & $\begin{array}{c}\text { No dedicated infrastructure, cyclists } \\
\text { use the road }\end{array}$ \\
\hline 16 & $\begin{array}{l}\text { Górowo } \\
\text { Iławeckie }\end{array}$ & $\mathrm{P}$ & OT & 5 & 7 & $\begin{array}{c}\text { No dedicated infrastructure, cyclists } \\
\text { use the road }\end{array}$ \\
\hline 17 & Jeziorany & $\mathrm{P}$ & OT & 12 & 28 & $\begin{array}{c}\text { No dedicated infrastructure, cyclists } \\
\text { use the road }\end{array}$ \\
\hline 18 & Olsztynek & $\mathrm{N}$ & OT & 19 & 16 & $\begin{array}{c}\text { No dedicated infrastructure, cyclists } \\
\text { use the road }\end{array}$ \\
\hline 19 & Pasym & $\mathrm{N}$ & OT & 15 & 11 & $\begin{array}{c}\text { No dedicated infrastructure, cyclists } \\
\text { use the road }\end{array}$ \\
\hline 20 & Ryn & $\mathrm{P}$ & OT & 16 & 20 & $\begin{array}{l}\text { No dedicated infrastructure, cyclists } \\
\text { use the road }\end{array}$ \\
\hline 21 & Wydminy & $\mathrm{P}$ & OT & 71 & 39 & $\begin{array}{c}\text { No dedicated infrastructure, cyclists } \\
\text { use the road }\end{array}$ \\
\hline
\end{tabular}

${ }^{*}$ Provincial road $(\mathrm{P})$, National road $(\mathrm{N}),{ }^{* *}$ in town $(\mathrm{T})$, outside town $(\mathrm{OT})$.

\subsection{Analysis of Cyclist Accidents}

According to National Police road accident statistics in 2010 [65], cyclists were involved in 3918 road accidents out of a total of 38,832 of all accidents (about 10\%). There were 290 cyclist fatalities and 3806 cyclist injuries. Cyclists were responsible for 1588 accidents, of which as many as 1328 occurred in a built-up area and only 260 in a non-built-up area. There was a higher share of fatal accidents outside towns compared to fatal accidents in urban areas, with every fourth accident ending in death which represents $25 \%$ ( 65 people in 260 accidents). In built-up areas, every 17th accident was fatal (78 people in 1328 accidents-6\%) [65].

The statistics in 2015 [66] are as follows: Cyclists were involved in 4634 road accidents out of a total of 32,967 accidents (about 14\%), with as many as 300 cyclists killed and 4111 injured. Most accidents occurred in a built-up area-4011, and there were 623 accidents in non-built-up areas. Just as in 2010, the share of fatalities in non-built-up areas was higher than in built-up areas and represented 
about 20\% (126 fatalities in 623 accidents). In 4011 accidents in built-up areas 174 people were killed, which accounted for only $4 \%$ (Figure 8 ).

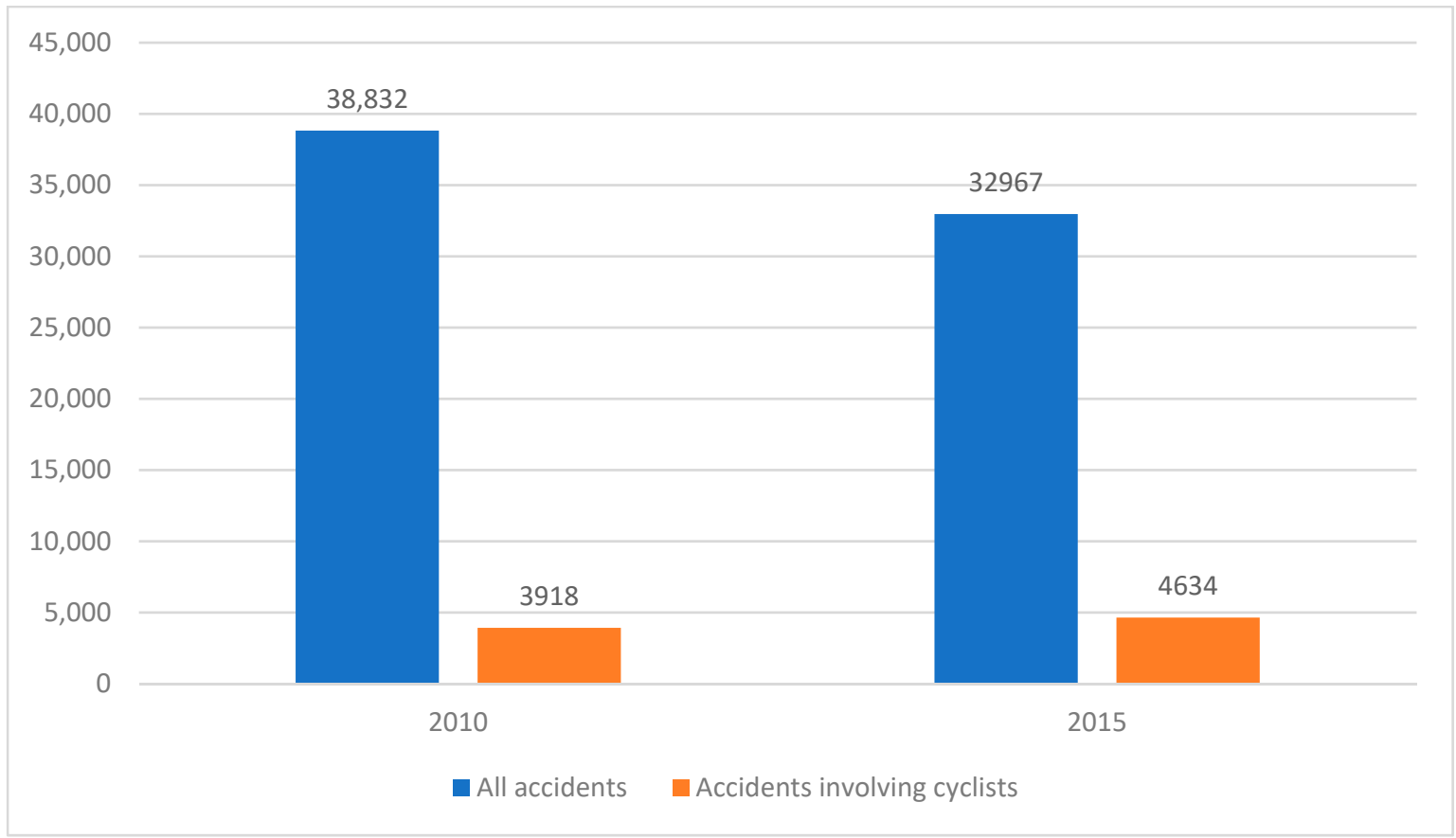

Figure 8. Comparison between cyclist accidents and overall accidents in 2010 and 2015-general data-Poland. Source: Own elaboration of authors based on data of the National Police $[65,66]$.

In the case of roads in Cittaslow towns, cyclist accidents are as follows. In 2010, on regional roads passing through the Cittaslow towns there were 15 cyclist incidents, of which 8 were accidents (including fatality accidents) and 7 were collisions. In relation to overall incidents on sections of those roads, there were 691, of which 77 were accidents and 614 were collisions, cyclist collisions represent about $1.1 \%$ of all collisions but cyclist accidents account for as much as $10 \%$ of all accidents. In 2015, in Cittaslow towns (on regional roads) there were 15 incidents, of which only 4 were accidents (injury or death). The total number of that year's incidents on the analysed roads amounted to 513, of which 63 were accidents; cyclist collisions represented only about $2.4 \%$ (11 cyclist collisions out of 450 of all collisions) and cyclist accidents represented 6.3\% (4 accidents out of a total of 63) [64], Figure 9.

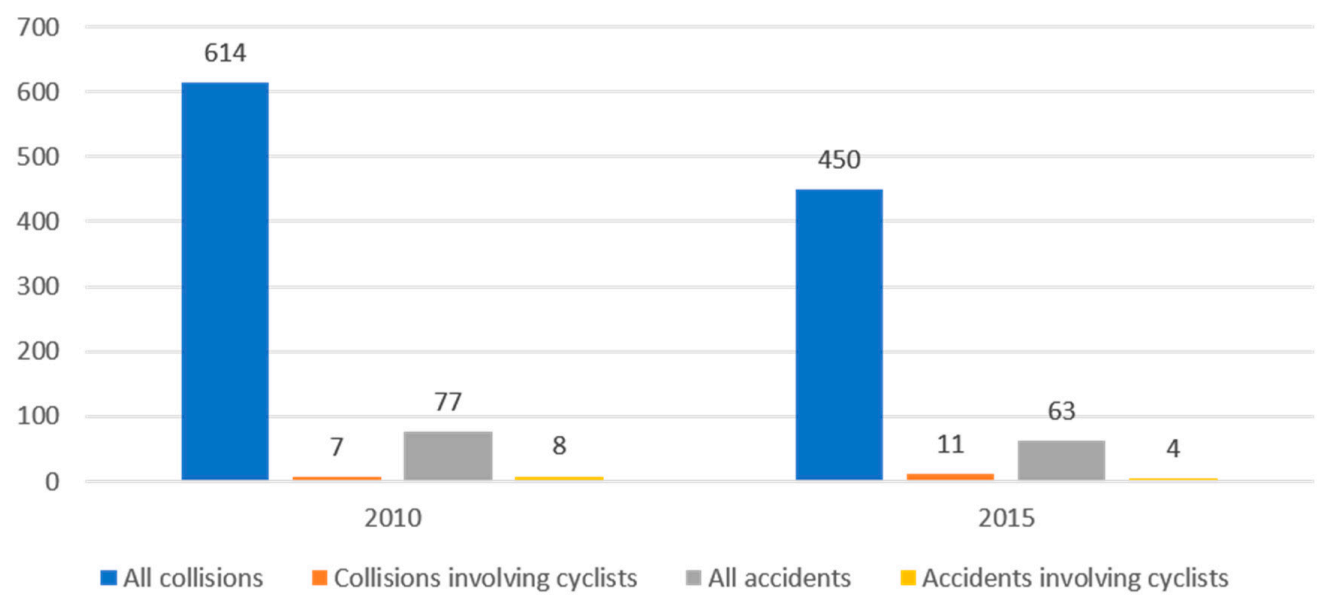

Figure 9. Comparison between cyclist accidents and overall accidents-regional roads of Cittaslow in 2010 and 2015. Own elaboration of authors based on ZDW in Olsztyn [53]. 
A comparison between cyclist accidents in Poland and cyclist accidents on regional roads in Cittaslow Warmia and Mazury towns shows that cyclist accidents in 2010 and 2015 accounted for a very small percentage of all accidents. Analysis of cyclist incidents in relation to all incidents in Cittaslow towns on regional roads also shows a small share, which is a puzzling result. This can be explained by analysing the share of other vehicles compared to bicycles (bicycles represented only about $2.39 \%$ in 2010 and $3.03 \%$ in 2015 of all traffic on regional roads), the underdeveloped cycling infrastructure (most of the cycling infrastructure can be found in and around towns, and outside towns cyclists mainly use the road) and a sense of vulnerability (the bicycle compared to other motor vehicles, including trucks). As a consequence, cycling is still an unpopular means of transport.

\subsection{Results of Analysis of the Supra-Local Revitalisation Programme of Cittaslow Towns for Its Cycling} Infrastructure Planning (First Programme from 2015, Individual Programmes 2016-2017, Second Programme from 2019)

It was found that under the First Revitalisation Programme of Cittaslow Towns of 2015, cycling infrastructure projects (both new and improved infrastructure) represented an important part of all projects (including social and economic projects). Project were designed to increase physical activity by encouraging the residents of the towns to cycle (in Barczewo, as an example). Social integration and a better environment were important factors in all projects. What is more, some of the infrastructure work was to be delivered by local entrepreneurs and job seekers or trainees (in Biskupiec, as an example). Project objectives included protection of the environment, in particular the conservation of wildlife (in Nowe Miasto Lubawskie, as an example) and $\mathrm{CO}_{2}$ reduction by giving up using cars and changing the energy mix. In some cases, cycling infrastructure was to run through conservation areas with plans to improve or reproduce historic roadways (in Bisztynek, as an example). Despite a strong emphasis on cycling infrastructure in the programme objectives, the majority of cycle path projects were designed as an addition to other activities such as public utility projects. While there is nothing wrong with combining projects, this led to a shortening of cycling routes and increased spending on non-cycling elements such as leisure infrastructure, parks and other uses. On the other hand, the additional functions along the routes may attract more cyclists, including families who will take rides to specific leisure sites.

The next conclusion from the analysis of cycling infrastructure projects is that there are no cycle paths (in Barczewo, as an example) or they are fragmented. The majority of the towns only have fragments of signed and prepared paths (with cycle lanes), but cycling, if any is done, happens on pavements or on the road. This is associated with the risk of a collision and crashing into a pedestrian or a car. Only some of the projects plan connections into existing routes or provision of good transport links in the town. In addition, the links into suburbs or villages are poor or non-existent, which may be a problem for the daily commutes by bicycle (a matter of safety), making the choice of bicycle as a means of transport less likely (in Biskupiec, as an example). With no plans to build links into areas outside the town, the original railway embankments remain an untapped potential for cycling (Nowe Miasto Lubawskie was the only town to suggest that), see Table 4.

Only a small number of the projects are designed to offer the city bike and build bike stations and cycle parking. Only three towns (Gołdap, Nowe Miasto Lubawskie, Olsztynek) have offered to do this. This is quite important because big cities in Poland have bike systems and renting bikes is very popular with both residents and tourists.

A key finding in the analysis of all the documents from the three periods $(2015-2017,2019)$ is that there are no measures to prepare cycling infrastructure. While the Supra-Regional Revitalisation Programme of Cittaslow Towns of 2015 included such projects, their number fell gradually in the subsequent years. The programme of 2019 does not include such projects or it gives them little importance. Although initially given priority, the projects are mere additions to other projects (e.g., in Bisztynek, Lubawa, Nowe Miasto Lubawskie, Olsztynek). It is safe to say that cycling infrastructure has been marginalised and previous plans will not be delivered at this stage. In the 
Second Programme (2019) only one of the cycle path projects was given priority (Górowo Iławeckie), a few are supplementary and the majority are not even included in the Programme. Results of the analysis are shown in Table 5.

Table 4. Connecting planned paths with other parts of the town and existing cycling paths (as planned in the 2015 programme).

\begin{tabular}{cccc}
\hline Town & $\begin{array}{c}\text { Better Links to Other } \\
\text { Parts of the Town }\end{array}$ & $\begin{array}{c}\text { Links into Existing Cycle Paths, } \\
\text { Including Supra-Local Paths }\end{array}$ \\
\hline 1 & Barczewo & $\mathrm{Y}$ & $\mathrm{N}$ \\
2 & Biskupiec & $\mathrm{Y}$ & $\mathrm{N}$ \\
3 & Bisztynek & $\mathrm{Y}$ & - \\
4 & Dobre Miasto & $\mathrm{Y}$ & $\mathrm{N}$ \\
5 & Gołdap & $\mathrm{Y}$ & $\mathrm{N}$ \\
6 & Górowo Iławeckie & $\mathrm{Y}$ & $\mathrm{N}$ \\
7 & Lidzbark Warmiński & - & - \\
8 & Lubawa & $\mathrm{Y}$ & $\mathrm{N}$ \\
9 & Nidzica & - & - \\
10 & Nowe Miasto Lubawskie & $\mathrm{Y}$ & $\mathrm{N}$ \\
11 & Olsztynek & $\mathrm{Y}$ & $\mathrm{N}$ \\
12 & Pasym & - & - \\
\hline
\end{tabular}

Y: yes, N: no, -: not applicable, no project/activity.

Table 5. Analysis of projects related to cycling infrastructure in Cittaslow cities (planned, for implementation, not implemented).

\begin{tabular}{|c|c|c|c|c|c|c|}
\hline & Town & Location & $\begin{array}{l}\text { Objective Involving Cycling } \\
\text { Infrastructure * }\end{array}$ & $\begin{array}{l}\mathrm{MP} / \mathrm{SP} / \mathrm{NP} \\
\mathrm{RPC}\end{array}$ & $\begin{array}{l}\text { MP/SP/NP } \\
\text { LRP *** }\end{array}$ & $\begin{array}{l}\mathrm{MP} / \mathrm{SP} / \mathrm{NP} \\
\mathrm{RPC} * * * *\end{array}$ \\
\hline \multirow[t]{2}{*}{1} & Barczewo & 2 & $\begin{array}{l}\text { Improve the pedestrian and } \\
\text { cycle path in the Old Town }\end{array}$ & MP & SP & NP \\
\hline & & & $\begin{array}{l}\text { Design of a pedestrian and } \\
\text { cycle path with infrastructure } \\
\text { along the river Pisa }(2.5 \mathrm{~km})\end{array}$ & MP & SP & SP \\
\hline 2 & Bartoszyce & - & - & No data & No data & $\mathrm{N}$ \\
\hline 3 & Biskupiec & 4 & $\begin{array}{c}\text { Planning of new cycle path in } 4 \\
\text { locations in the town }\end{array}$ & MP & No data & $\begin{array}{l}\mathrm{SP}(1 \mathrm{~km} \\
\text { of path) }\end{array}$ \\
\hline 4 & Bisztynek & 1 & $\begin{array}{l}\text { Design of a cycling and } \\
\text { educational route in an area of } \\
\text { revitalisation, } 4.2 \mathrm{~km}\end{array}$ & MP & NP & NP \\
\hline 5 & $\begin{array}{l}\text { Dobre } \\
\text { Miasto }\end{array}$ & 1 & $\begin{array}{l}\text { Design of pedestrian and cycle } \\
\text { paths along the river Łyna, } 4.5 \\
\text { km (including pedestrian } \\
\text { walks) }\end{array}$ & No data & No data & NP \\
\hline 6 & Działdowo & - & - & No data & No data & NP \\
\hline 7 & Gołdap & 1 & $\begin{array}{l}\text { Build a well-lit cycle path and } \\
\text { implement city bike project }\end{array}$ & SP & NP & NP \\
\hline 8 & $\begin{array}{l}\text { Górowo } \\
\text { Iław. }\end{array}$ & 2 & $\begin{array}{l}\text { Build a pedestrian and cycle } \\
\text { path in the park } \\
\text { In the river Młynówka valley }\end{array}$ & $\begin{array}{l}\text { SP } \\
\text { SP }\end{array}$ & $\begin{array}{l}\text { NP } \\
\text { MP }\end{array}$ & $\begin{array}{c}\mathrm{NP} \\
\mathrm{MP}(0.7 \\
\mathrm{km} \text { of } \\
\text { path })\end{array}$ \\
\hline 9 & Jeziorany & - & - & No data & No data & $\mathrm{NP}$ \\
\hline 10 & Lidzbark & - & $\begin{array}{c}\text { Bike rental } \\
\text { None in } 2015 \text { a section of a }\end{array}$ & No data & No data & $\mathrm{SP}$ \\
\hline 11 & $\begin{array}{l}\text { Lidzbark } \\
\text { Wam. }\end{array}$ & & $\begin{array}{l}\text { None, in } 2015 \text { a section of a } \\
\text { cycling route was built, part of } \\
\text { the North East Poland cycling } \\
\text { route (measure not part of the } \\
\text { Programme) }\end{array}$ & NP & NP & NP \\
\hline 12 & Lubawa & 1 & $\begin{array}{c}\text { Build a pedestrian and cycle } \\
\text { path Zalew-Lipy, cycle path } \\
3.05 \mathrm{~km} \text { pedestrian and cycle } \\
\text { path } 0.4 \mathrm{~km}\end{array}$ & MP & NP & NP \\
\hline
\end{tabular}


Table 5. Cont.

\begin{tabular}{|c|c|c|c|c|c|c|}
\hline & Town & Location & $\begin{array}{l}\text { Objective Involving Cycling } \\
\text { Infrastructure * }\end{array}$ & $\begin{array}{l}\mathrm{MP} / \mathrm{SP} / \mathrm{NP} \\
\mathrm{RPC} * *\end{array}$ & $\begin{array}{l}\mathrm{MP} / \mathrm{SP} / \mathrm{NP} \\
\mathrm{LRP}^{* * *}\end{array}$ & $\begin{array}{l}\mathrm{MP} / \mathrm{SP} / \mathrm{NP} \\
\mathrm{RPC} * * * *\end{array}$ \\
\hline 13 & Nidzica & - & $\begin{array}{l}\text { No planned cycle paths. The } \\
\text { city centre is to be closed for } \\
\text { motor traffic }\end{array}$ & NP & NP & NP \\
\hline 14 & $\begin{array}{c}\text { Nowe } \\
\text { Miasto Lub. }\end{array}$ & 2 & $\begin{array}{c}\text { Build a cycle path on } \\
\text { post-railway site } \\
\text { Build a bike station (bike rental) }\end{array}$ & $\begin{array}{l}M \\
M\end{array}$ & $\begin{array}{l}S \\
S\end{array}$ & $\begin{array}{l}\mathrm{N} \\
\mathrm{N}\end{array}$ \\
\hline 15 & Olsztynek & 1 & $\begin{array}{l}\text { Build a cycle path and buy } \\
\text { bikes }\end{array}$ & M & S & $\mathrm{N}$ \\
\hline 16 & Orneta & - & - & No data & No data & $\mathrm{N}$ \\
\hline 17 & Pasym & - & $\begin{array}{c}\text { No projects to build path } \\
\text { infrastructure, pedestrian paths } \\
\text { only }\end{array}$ & $\mathrm{N}$ & $\mathrm{N}$ & $\mathrm{N}$ \\
\hline 18 & Reszel & 1 & $\begin{array}{c}\text { Build pedestrian and cycle } \\
\text { paths in the city park, } 1.5 \mathrm{~km} \\
\text { long } \\
\text { Improve the quality of cycle } \\
\text { paths in the city centre }\end{array}$ & $\begin{array}{c}M \\
S\end{array}$ & $\begin{array}{l}\mathrm{M} \\
\mathrm{N}\end{array}$ & $\begin{array}{l}\mathrm{S} \\
\mathrm{N}\end{array}$ \\
\hline 19 & Ryn & - & $\begin{array}{l}\text { No projects to build cycle paths, } \\
\text { improving lakeside pedestrian } \\
\text { paths only }\end{array}$ & $\mathrm{N}$ & $\mathrm{N}$ & $\mathrm{N}$ \\
\hline
\end{tabular}

* including selected elements such as road infrastructure, bridges, car parks, stops, sport facilities, outdoor gyms, playgrounds, city furniture, lighting, CCTV, information, education, therapeutic elements, roadside vegetation, security; MP: Main project, SP: Supplementary Project, NP: no project; ** RPCT—Regional Revitalisation Programme of Cittaslow Town (2015); *** LPCT-Local Revitalisation Programme of Cittaslow Town (2016-2017); **** RPCT—Regional Revitalisation Programme of Cittaslow Towns (2019).

\section{Guidelines and Recommendations for the Development of Cycling Infrastructure and for Road Safety}

\subsection{Specific Guidelines Based on the Research}

\subsubsection{Guidelines for Cycling Policy}

- Cooperation between administrative bodies and road authorities and other bodies responsible for road infrastructure to develop guidelines for safe cycling infrastructure and cyclist safety on the road. Formulate local guidelines for road authorities, for example by consulting city authorities. Roads in Poland and in Warmia and Mazury are typically managed by a number of bodies which creates problems with planning. Having local guidelines for safe infrastructure and cyclist safety for each town would improve and accelerate the planning and construction of cycle paths as part of all roads.

- Develop cycling policy strategies for Cittaslow towns to take account of their unique character and demand for cycling infrastructure of people who commute between towns. The strategies should be based on a diagnosis of the individual towns and analysis of local conditions. As an example, the strategies of Braniewo, Bartoszyce and Gołdap and their suburban villages should be related to the towns' close proximity to the state border with the Kaliningrad Region (Russia). This is because a cycle link must be ensured between these towns and the border crossing, the workplace for many commuters. On the other hand, this opens up new opportunities for tourism. The towns of Barczewo (and the areas outside it), Dobre Miasto and Olsztynek should focus their strategies on providing links to jobs and services in the regions' biggest towns (with the distance as an important criterion).

- Develop and correlate other cycling infrastructure projects locally, regionally and nationally, making sure that there is a general cycle path strategy rather than isolated solutions (this is a common problem in Warmia and Mazury, especially in small towns, but the rest of Poland is no different); a comprehensive approach is needed to include existing sections and add new ones. 
- Reinstate the original projects from the Supra-Local Revitalisation Programme of Cittaslow Towns of 2015 and generate new cycling infrastructure projects by including them in the new programme. Some of the priority actions would be to implement the city bike project in Gołdap, Lidzbark and Nowe Miasto Lubawskie and develop similar projects in the other towns. Furthermore, the pavement along the regional road in Dobre Miasto to be constructed in 2020 should be correlated with a new cycle path. It is important to plan pavements and cycle paths at the same time as opposed to planning pavements only.

\subsubsection{Guidelines for Planning Infrastructure and Environmental Solutions}

- Connect existing paths in the towns into a uniform transport system to include sections of national, regional, county, municipal and local roads. This requires the cooperation of the Regional Roads Authority and the General Directorate for National Roads and Motorways with town mayors to ensure a joint effort and cost-sharing when building new or upgrading existing cycling infrastructure. Decisions to link cycle paths should be based on local guidelines previously agreed to between road authorities and city authorities. Joint implementation and cost-sharing may be part of the guidelines.

- Plan and build new paths as dedicated roadside/street lanes (in and outside the town) and separate them from pavements or crossings as a separate lane (especially in towns). It is clear that densely developed parts of the towns under analysis cannot accommodate dedicated cycle paths. As a result, the proposal is to convert one of the pavements into a cycle path like this: convert the pavement on one side of the Łużycka street in Dobre Miasto and the Wojska Polskiego street in Nowe Miasto Lubawskie into a cycle path.

- Connect cycle paths in the town and extend them into rural areas. This should be a priority objective for all the towns under analysis.

- Plan for accompanying cycling infrastructure and path development through landscaping, especially where public spaces are concerned such as parks, squares, plazas e.g., in Biskupiec, Dobre Miasto, Lidzbark Warmiński, Gołdap, Bartoszyce.

\subsubsection{Guidelines for Improving Safety and Accident Statistics}

- Conduct detailed cycle traffic counts as separate from the General Traffic Count. Cycle traffic counts should be conducted at least twice a year-at the beginning and end of the cycling season; traffic should be studied off-season to understand whether cycling is a seasonal or year-round activity.

- Monitor, analyse and improve road infrastructure in high risk sites for cycling. Analyse cyclist accident databases, put up CCTV in accident sites and analyse the data collected to identify the cause and develop solutions.

- Separate cycle paths clearly from other road users (especially from cars and pedestrians), primarily in towns and outside of them. Apply physical barriers between cycle traffic and motor traffic such as greenery or road barriers, separate pedestrians from cyclists by raising pavements in relation to cycle paths or by separating the two surfaces.

\subsection{General Recommendations}

- Conduct an analysis of good practice from Cittaslow towns worldwide which have successfully implemented and are running cycling infrastructure and safety projects. This solution can be easily taken up in the form of joint initiatives between Polish Cittaslow towns and transport and planning (which includes cycle path development) specialists from Cittaslow towns in, for example, the Netherlands, Germany, the Nordic Cittaslow Network. 
- Correlate educational programmes on safety with the educational activities of schools, police, municipal guards, public administration and all entities involved in transport, road traffic and health.

- Joint activities to promote cycling as a means of transport for all Cittaslow towns using thematic meetings and events for the communities. Promote active leisure for families with the bicycle as a means of transport.

- Create a system to enable the free transport of bicycles by other means of transport over longer distances. This includes rail transport to carry bicycles free of charge from Braniewo, Nidzica, Olsztynek, Pasym, Barczewo to Olsztyn, the region's biggest town. It also includes a proposal to allow people to cycle from the town or village to a train station and then continue the trip by train (a solution commonly used in the countries of Western Europe, not so much in Poland).

- Prepare specimens of materials for paths and path surfaces to follow the local character and environmental requirements (e.g., paved or bituminous paths). Keep all types and colours of surfaces the same in Cittaslow towns, ensuring a more intuitive cycling.

- Identify ways to use the potential of the environment in ensuring that cycling routes pass through attractive countryside.

- Plan for green areas which are best run along paths with trees, shrubs and low growth. Using low growth in dedicated sections in Bartoszyce and Lidzbark Warmiński to physically separate bicycles from cars would replace road barriers which are not as aesthetic. A similar solution has already been applied in Działdowo.

- Use distinct horizontal marking for cyclist crossings on main roads (preferably red marking), primarily in non-built-up areas. Horizontal marking of the same colour as the cycle path (preferably red) every time the path crosses the road.

- Use additional vertical marking in places where cyclists cross the road (including fluorescent marking) to warn other road users.

- Where cyclist crossings cross minor roads, keep cyclist crossings away from the main road and run them perpendicularly to the minor road, "deflecting" the cycling route before the cycle crossing.

- Use elements of traffic calming, especially in the town centre and areas of heavy motor traffic. To get motorists to slow, use raised cycle crossings and narrower cross-sections by designating cycle paths that are made distinct from the road by separators and colour (red).

- Use contraflow lanes physically separated from the road as separate cycle lanes to allow cyclists to ride "against the flow" in towns in specific areas.

\section{Conclusions}

The article addresses the topic of cycling infrastructure to be introduced in Cittaslow towns in the region of Warmia and Mazury, in line with Cittaslow statutes and strategies which focus on the environment and community issues. It also aims to analyse the share of cycling as a means of transport in towns which are members of this organisation and in other small towns across Poland. There are no previous publications related to this topic. The authors have analysed transport space and its use in the context of availability and road safety and in relation to the projects included in revitalisation programmes.

It was established in the research that cycle paths in the Cittaslow towns only have a limited presence on national and regional roads. The existing cycling infrastructure is not adequately developed. Existing cycle paths are not connected with one another, the routes are incomplete and cycling on the road is difficult and dangerous.

The results of the analyses in this work have led us to the following conclusions. As regards the number of bicycles, it is important to study cycle traffic in more detail. As well as conducting general traffic counts every five years, more frequent counts should be carried out to measure cycle traffic specifically and how it relates to other road users. This will help to analyse the needs of cycle traffic 
and cycling infrastructure and to understand the safety of cyclists and other road users. As we can see from analysis of cycling infrastructure, cycling increases where new cycle paths and roads have been built, i.e., usually in urban areas. The results of infrastructure analysis in this work show that while cycle paths across Poland are growing in number (although not so much in Cittaslow towns), rural and out-of-town infrastructure is scarce which translates into very little cycle traffic. In the case of the analysed Cittaslow suburban areas, potential cyclists probably do not feel safe there. Please note that the problem of feeling that cycling on the road is unsafe is not confined to Poland only. The work gives examples from other countries which suggest a similar problem. Given the characteristics of Cittaslow towns defined in the organisation's programme, i.e., safety and better living standards, it is clear that unless the cycling infrastructure is improved in the towns and outside them, these assumptions will not be met fully.

The results of cyclist accident analysis on the roads we have studied show that there are not many accidents involving cyclists. While this may be viewed as a positive result, it may not in fact be the case when we consider the low share of cycling in overall traffic, the underdeveloped cycling infrastructure and the resulting sense of feeling unsafe when cycling outside of dedicated cycling infrastructure.

To make the picture complete, there needs to be an adequate plan for cycling infrastructure development and a determined effort to deliver that plan. It is clear from the analysis of the Revitalisation Programme of Cittaslow Towns regarding cycling infrastructure, that in 2019 cycling projects were made secondary despite the priority they were given in the 2015 programmes which aimed to promote cycling as a way to increase levels of physical activity, improve the environment, protect nature and reduce $\mathrm{CO}_{2}$ emissions. The article has demonstrated that there is a close relation between abandoning plans to improve and build more cycle paths and cyclist safety, especially on rural roads.

It is claimed in the article that bicycles should be used as a basic and everyday means of transport, especially by residents of suburban areas and not just for tourism.

Author Contributions: Conceptualization, A.J.; methodology, A.J. and A.M.; analysis, A.J., J.Ż. and A.M.; investigation, A.J., J.Ż. and A.M.; writing preparation and visualization, A.J. and A.M. All authors have read and agreed to the published version of the manuscript.

Funding: This research received no external funding.

Conflicts of Interest: The authors declare no conflict of interest.

\section{References}

1. Kristianova, K. Public space connectivity and walkability in suburban neighborhoods-Case studies from Nitra and Košice, Slovakia. In Proceedings of the International Multidisciplinary Scientific GeoConference: SGEM: Surveying Geology \& Mining Ecology Management, Albena, Bulgaria, 28 June-6 July 2016; pp. 675-682. [CrossRef]

2. Kwiatkowski, A. Urban Cycling as an Indicator of Socio-Economic Innovation and Sustainable Transport. Quaest. Geogr. 2018, 37, 23-32. [CrossRef]

3. McLeod, S.; Scheurer, J.; Curtis, C. Urban Public Transport: Planning Principles and Emerging Practice. J. Plan. Lit. 2017, 32, 223-239. [CrossRef]

4. Kazak, J.; Chalfen, M.; Kamińska, J.; Szewrański, S.; Świąder, M. Geo-Dynamic Decision Support System for Urban Traffic Management. In Dynamics in GIscience, Proceedings of GIS Ostrava, Ostrava, Czech Republik, 21-23 March 2018; Lecture Notes in Geoinformation and Cartography; Ivan, I., Horák, J., Inspektor, T., Eds.; Springer: Cham, Switzerland, 2018.

5. Kazak, J.; Garcia Castro, D.; Swiader, M.; Szewranski, S.Z. Decision Support System in Public Transport Planning for Promoting Urban Adaptation to Climate Change. IOP Conf. Ser. Mater. Sci. Eng. 2019, 471. [CrossRef]

6. Fraser, S.D.S.; Lock, K. Cycling for transport and public health: A systematic review of the effect of the environment on cycling. Eur. J. Public Health 2011, 21, 738-743. [CrossRef] [PubMed] 
7. Aletta, F.; Van Renterghem, T.; Botteldooren, D. Influence of Personal Factors on Sound Perception and Overall Experience in Urban Green Areas. A Case Study of a Cycling Path Highly Exposed to Road Traffic Noise. Int. J. Environ. Res. Public Health 2018, 15, 1118. [CrossRef] [PubMed]

8. Hull, A.; O'Holleran, C. Bicycle infrastructure: Can good design encourage cycling? Urban Plan. Transp. Res. 2014, 2, 369-406. [CrossRef]

9. Sarjala, S. Built environment determinants of pedestrians' and bicyclists' route choices on commute trips: Applying a new grid-based method for measuring the built environment along the route. J. Transp. Geogr. 2019, 78, 56-69. [CrossRef]

10. Fishman, E. Cycling as transport. Transp. Rev. 2016, 36, 18. [CrossRef]

11. Li, H. Study on Green Transportation System of International Metropolises. Procedia Eng. 2016, 137, 762-771. [CrossRef]

12. Buehler, R.; Pucher, J.; Gerike, R.; Götschi, T. Reducing car dependence in the heart of Europe: Lessons from Germany, Austria, and Switzerland. Transp. Rev. 2017, 37, 4-28. [CrossRef]

13. Frondela, M.; Vance, C. Cycling on the extensive and intensive margin: The role of paths and prices. Transp. Res. Part A Policy Pract. 2017, 104, 21-31. [CrossRef]

14. Silva, C.; Teixeira, J.; Proenca, A.; Bicalho, T.; Cunha, I.; Aguiar, A. Revealing the cycling potential of starter cycling cities: Usefulness for planning practice. Transp. Policy 2019, 81, 38-147. [CrossRef]

15. OECD/ITF. Transition to Shared Mobility_How Large Cities Can Deliver Inclusive Transport Services; Raport of the International Transport Forum: Paris, France, 2017; pp. 1-54. Available online: www.itf-oecd.org (accessed on 5 May 2020).

16. Kristianova, K.; Marcinkova, D. Cestné komunikácie ako verejný priestor a cestná zeleň. In Perspektivy Území III: Veřejné Prostory a Prostranství; ČVUT: Prague, Czech Republic, 2015; pp. 50-55. Available online: http://adminu.lhosting4.cz/Include/Data/getfile.php?id=1756\&db=uzemieu (accessed on 10 May 2020).

17. Cervero, R.; Duncan, M. Walking, Bicycling, and Urban Landscapes: Evidence from the San Francisco Bay Area. Am. J. Public Health 2003, 93, 1478-1483. [CrossRef] [PubMed]

18. Sturiale, L.; Scuderi, A. The Evaluation of Green Investments in Urban Areas: A Proposal of an eco-social-green Model of the City. Sustainability 2018, 10, 4541. [CrossRef]

19. Cervero, R.; Denman, S.; Jin, Y. Network design, built and natural environments and bicycle commuting: Evidence from British cities and towns. Transp. Policy 2019, 74, 153-164. [CrossRef]

20. Campos-Sánchez, F.S.; Valenzuela-Montes, L.M.; Abarca-Álvarez, F.J. Evidence of Green Areas, Cycle Infrastructure and Attractive Destinations Working together in Development on Urban Cycling. Sustainability 2019, 11, 4730. [CrossRef]

21. Fernández-Heredia, A.; Monzón, A.; Jara-Díaz, S. Understanding cyclists' perceptions, keys for a successful bicycle promotion. Transp. Res. Part A Policy Pract. 2014, 63, 1-11. [CrossRef]

22. Ogilvie, D.; Egan, M.; Hamilton, V.; Petticrew, M. Promoting walking and cycling as an alternative to using cars: A systematic review. BMJ 2004, 329, 763-776. [CrossRef]

23. Cohen, B.; Kietzmann, J. Ride On! Mobility Business Models for the Sharing Economy. Organ. Environ. 2014, 27, 279-296. [CrossRef]

24. Drużyńska, P.; Knysak, J.; Świąder, M.; Kazak, J. Assessment of the Effectiveness of the Wrocław City Bike. Acta Sci. Pol. Adm. Locorum 2016, 15, 33-45.

25. Scotini, R.; Skinner, I.; Racioppi, F.; Fusé, V.; Bertucci, J.D.O.; Tsutsumi, R. Supporting Active Mobility and Green Jobs through the Promotion of Cycling. Int. J. Environ. Res. Public Health 2017, 14, 1603. [CrossRef] [PubMed]

26. Meenar, M.; Flamm, B.; Keenan, K. Mapping the Emotional Experience of Travel to Understand Cycle-Transit User Behavior. Sustainability 2019, 11, 4743. [CrossRef]

27. Dill, J. Bicycling for Transportation and Health: The Role of Infrastructure. J. Public Health Policy 2009, 30, 95-110. [CrossRef] [PubMed]

28. Maas, J.; Verheij, R.A.; Spreeuwenberg, P. Physical activity as a possible mechanism behind the relationship between green space and health: A multilevel analysis. BMC Public Health 2008, 8, 206. [CrossRef]

29. Li, A.; Huanga, Y.; Axhausen, K.W. An approach to imputing destination activities for inclusion in measures of bicycle accessibility. J. Transp. Geogr. 2020, 82, 102566. [CrossRef]

30. Oja, P.; Titze, S.; Bauman, A.; De Geus, B.; Krenn, P.; Reger-Nash, B.; Kohlberger, T. Health benefits of cycling: A systematic review. Scand. J. Med. Sci. Sports 2011, 21, 496-509. [CrossRef] [PubMed] 
31. Lee, I.-M.; Shiroma, E.J.; Lobelo, F.; Puska, P.; Blair, S.N.; Katzmarzyk, P.T. Effect of physical inactivity on major non-communicable diseases worldwide: An analysis of burden of diseases and life expectancy. Lancet 2012, 380, 219-229. [CrossRef]

32. Bauman, A.E.; Reis, R.S.; Sallis, J.F.; Wells, J.C.; Loos, R.J.; Martin, B.W. Correlates of physical activity: Why are some people physically active and others not? Lancet 2012, 380, 258-271. [CrossRef]

33. Götschi, T.; Garrard, J.; Giles-Corti, B. Cycling as a Part of Daily Life: A Review of Health Perspectives. Transp. Rev. 2016, 36, 45-71. [CrossRef]

34. Pucher, J.; Dijkstra, L. Promoting Safe Walking and Cycling to Improve Public Health: Lessons from the Netherlands and Germany. Am. J. Public Health 2003, 93, 1509-1516. [CrossRef]

35. Lakerveld, J.; Woods, C.; Hebestreit, A.; Brenner, H.; Flechtner-Mors, M.; Harrington, J.M.; Kamphuis, C.B.M.; Laxyi, M.; Luszczynska, A.; Mazzocchi, M.; et al. Advancing the evidence base for public policies impacting on dietary behaviour, physical activity and sedentary behaviour in Europe: The Policy Evaluation Network promoting a multidisciplinary approach. Food Policy 2020. [CrossRef]

36. Gutierrez, M.; Cantillo, V.; Arellana, J.; Ortúzar, J. Estimating bicycle demand in an aggressive environment. Int. J. Sustain. Transp. 2020,1-14. [CrossRef]

37. Ortúzar, J. Sustainable Urban Mobility: What Can Be Done to Achieve It? J. Indian Inst. Sci. 2019, 99, 683-693. [CrossRef]

38. Fallon Mayers, R.; Glover, T.D. Whose Lane Is It Anyway? The Experience of Cycling in a Mid-Sized City. Leis. Sci. 2019. [CrossRef]

39. Reynolds, C.C.; Harris, M.A.; Teschke, K.; Cripton, P.A.; Winters, M. The impact of transportation infrastructure on bicycling injuries and crashes: A review of the literature. Environ. Health 2009, 8, 47. [CrossRef]

40. Lawson, A.R.; Ghosh, B.; Pakrashi, V. Quantifying the perceived safety of cyclists in Dublin. Proc. Inst. Civ. Eng. Transp. 2015, 168, 290-299. [CrossRef]

41. Aldred, R.; Jungnickel, K. Why culture matters for transport policy: The case of cycling in the UK. J. Transp. Geogr. 2014, 34, 78-87. [CrossRef]

42. Helbich, M.; Böcker, L.; Dijst, M. Geographic heterogeneity in cycling under various weather conditions: Evidence from Greater Rotterdam. J. Transp. Geogr. 2014, 38, 38-47. [CrossRef]

43. Nosal, T.; Miranda-Moreno, L.F. The effect of weather on the use of North American bicycle facilities: A multi-city analysis using automatic counts. Transp. Res. Part A Policy Pract. 2014, 66, 213-225. [CrossRef]

44. Kachaniak, D.; Reducha, M.; Skrzyńska, J. Raport z Badania na Temat Uwarunkowań do Podejmowania Transportowej Aktywności Fizycznej Polaków; TNS POLSKA dla Ministerstwa Sportu i Turystyki Rzeczpospolitej Polskiej: Warszawa, Poland, 2015; p. 36. Available online: https://www.msit.gov.pl/pl/sport/badania-ianalizy/aktywnosc-fizyczna-spol/575 (accessed on 10 May 2020).

45. Bíla, M.; Bílová, M.; Müller, I. Critical factors in fatal collisions of adult cyclists with automobiles. Accid. Anal. Prev. 2010, 42, 1632-1636. [CrossRef]

46. Zawadzka, A.K. Making Small Towns Visible in Europe: The Case of Cittaslow Network-The Strategy Based on Sustainable Development. Transylv. Rev. Adm. Sci. 2017, 90-106. [CrossRef]

47. Jaszczak, A. The Future of Cittaslow Towns. Archit. Kraj. 2015, 1, 70-81.

48. Wierzbicka, W.; Farelnik, E.; Stanowicka, A. The Development of the Polish National Cittaslow Network. Olszt. Econ. J. 2019, 14, 113-125. [CrossRef]

49. Farelnik, E.; Stanowicka, A. Smart city, slow city and smart slow city as development models of modern cities. Olszt. Econ. J. 2016, 11. [CrossRef]

50. Jaszczak, A.; Kristianova, K. Social and Cultural Role of Greenery in Development of Cittaslow Towns. IOP Conf. Ser. Mater. Sci. Eng. 2019, 603, 032028. [CrossRef]

51. Ustawa z Dnia 21 Marca 1985 r. o Drogach Publicznych (Dz. U. 2020 poz. 470). Available online: http://prawo.sejm.gov.pl/isap.nsf/DocDetails.xsp?id=wdu19850140060 (accessed on 10 April 2020).

52. Available online: www.gddkia.gov.pl (accessed on 15 April 2020).

53. ZDW Olsztyn. Available online: http://www.zdw.olsztyn.pl/strona-glowna/aktualnosci.html?start=64 (accessed on 15 April 2020).

54. Opoczyński, K. Wytyczne Pomiaru Ruchu na Drogach Wojezódzkich w 2010 Roku; Generalna Dyrekecja Dróg i Autostrad: Warszawa, Poland, 2009. Available online: https://www.gddkia.gov.pl/userfiles/articles/g/ GENERALNY_POMIAR_RUCHU_2010/0.1.1.2_Wytyczne_DW_GPR_2010.pdf (accessed on 15 March 2020). 
55. Kowalski, K.; Kaplar, I.; Maśkiewicz, J.; Dobrzyński, Ł.; Wojdyński, R. Wytyczne Generalnego Pomiaru Ruchu w 2015 na Drogach Wojewódzkich; Generalna Dyrekcja Dróg Krajowych i Autostrad: Warszawa, Poland, 2014. Available online: https://www.gddkia.gov.pl/userfiles/articles/g/generalny-pomiarruchu-w-2015_15598/Wytyczne\%20GPR\%20na\%20dr\%20woj\%20w\%202015\%20r_zakceptowane_ok.pdf (accessed on 15 March 2020).

56. Opoczyński, K. Wytyczne Organizacji i Przeprowadzenia Generalnego Pomiaru Ruchu w 2010 na Drogach Krajowych; Załącznik do Zarządzenia nr 59 z Dnia 12.10.2009; Generalna Dyrekcja Dróg Krajowych i Autostrad: Warszawa, Poland, 2009. Available online: https://www.gddkia.gov.pl/userfiles/articles/g/ GENERALNY_POMIAR_RUCHU_2010/0.1.1.1_Wytyczne_GPR_2010.pdf (accessed on 15 March 2020).

57. Kowalski, K.; Kaplar, I.; Maśkiewicz, J.; Dobrzyński, Ł.; Wojdyński, R. Metoda Przeprowadzenia Generalnego Pomiaru Ruchu w Roku 2015; Generalna Dyrekecja Dróg i Autostrad: Warszawa, Poland, 2014. Available online: https://www.gddkia.gov.pl/userfiles/articles/z/zarzadzenia-generalnego-dyrektor_13901/ zarzadzenie\%2038\%20Zalacznik_b_Metoda\%20GPR\%202015.pdf (accessed on 15 March 2020).

58. Regional Operational Programme of the Voivodeship of Warmia and Mazury 2014-2020. Available online: https://ec.europa.eu/growth/tools-databases/regional-innovation-monitor/policy-document/regionaloperational-programme-voivodeship-warmia-and-mazury-2014-2020 (accessed on 15 April 2020).

59. Ponadlokalny Programu Rewitalizacji Miast Cittaslow. 2015. Available online: https://www.wmarr.olsztyn. pl/s/images/stories/Pliki/2015_06_08_Ponadlokalny_program_rewitalizacji_sieci_miast_Cittaslow.pdf (accessed on 10 February 2020).

60. Ponadlokalny Program Rewitalizacji Miast Cittaslow. 2019. Available online: https://cittaslowpolska.pl/ images/PDF/PPR_08_2019.pdf (accessed on 10 February 2020).

61. Raport "Transportowe Zwyczaje Polaków” dla Busradar.pl, January 2019. Available online: www.transportpubliczny.pl (accessed on 10 March 2020).

62. Bank Danych Lokalnych Głównego Urzędu Statystycznego. Available online: www.bdl.stat.gov.pl (accessed on 18 May 2020).

63. Łysoń, P.; Barlik, M.; Lewandowska, B.; Siwiak, K. Zeszyt Metodologiczny; Badanie Budżetów Gospodarstw Domowych; Główny Urząd Statystyczny, Departament Badań Społecznych: Warszawa, Poland, 2018. Available online: https://stat.gov.pl/download/gfx/portalinformacyjny/pl/defaultaktualnosci/5486/10/2/1/ zeszyt_metodologiczny_badanie_budzetow_gospodarstw_domowych.pdf (accessed on 15 April 2020).

64. GDDKiA Olsztyn. Available online: www.gddkia.gov.pl (accessed on 15 April 2020).

65. Symon, E. Wypadki Drogowe w Polsce w 2010r; Zespół Profilaktyki i Analiz Biura Ruchu Drogowego Komendy Głównej Policji: Warszawa, Poland, 2011. Available online: http://statystyka.policja.pl/st/ruch-drogowy/ 76562, wypadki-drogowe-raporty-roczne.html (accessed on 10 March 2020).

66. Symon, E. Wypadki Drogowe w Polsce w 2015r; Wydział Opiniodawczo-Analityczny Biura Ruchu Drogowego Komendy Głównej Policji: Warszawa, Poland, 2016. Available online: http://statystyka.policja.pl/st/ruchdrogowy/76562, wypadki-drogowe-raporty-roczne.html (accessed on 10 March 2020).

(C) 2020 by the authors. Licensee MDPI, Basel, Switzerland. This article is an open access article distributed under the terms and conditions of the Creative Commons Attribution (CC BY) license (http://creativecommons.org/licenses/by/4.0/). 